\title{
The Ecological Status of Juniperus foetidissima Forest Stands in the Mt. Oiti-Natura 2000 Site in Greece
}

\author{
Nikolaos Proutsos *D, Alexandra Solomou, George Karetsos, Konstantinia Tsagari, George Mantakas, \\ Konstantinos Kaoukis, Athanassios Bourletsikas and George Lyrintzis
}

Citation: Proutsos, N.; Solomou, A.; Karetsos, G.; Tsagari, K.; Mantakas,

G.; Kaoukis, K.; Bourletsikas, A.;

Lyrintzis, G. The Ecological Status of Juniperus foetidissima Forest Stands in the Mt. Oiti-Natura 2000 Site in Greece. Sustainability 2021, 13, 3544. https://doi.org/10.3390/su13063544

Academic Editor: Susana Santos

Received: 15 February 2021

Accepted: 19 March 2021

Published: 23 March 2021

Publisher's Note: MDPI stays neutral with regard to jurisdictional claims in published maps and institutional affiliations.

Copyright: (c) 2021 by the authors. Licensee MDPI, Basel, Switzerland. This article is an open access article distributed under the terms and conditions of the Creative Commons Attribution (CC BY) license (https:/ / creativecommons.org/licenses/by/ $4.0 /)$.
Hellenic Agricultural Organization "Demeter", Institute of Mediterranean Forest Ecosystems, Terma Alkmanos, 11528 Athens, Greece; solomou@fria.gr (A.S.); gekaretsos@yahoo.gr (G.K.); director@fria.gr (K.T.); mage@fria.gr (G.M.); kako@fria.gr (K.K.); mpat@fria.gr (A.B.); g.lyrintzis@yahoo.gr (G.L.)

* Correspondence: np@fria.gr; Tel.: +30-2107-787535

\begin{abstract}
Junipers face multiple threats induced both by climate and land use changes, impacting their expansion and reproductive dynamics. The aim of this work is to evaluate the ecological status of Juniperus foetidissima Willd. forest stands in the protected Natura 2000 site of Mt. Oiti in Greece. The study of the ecological status is important for designing and implementing active management and conservation actions for the species' protection. Tree size characteristics (height, breast height diameter), age, reproductive dynamics, seed production and viability, tree density, sex, and habitat expansion were examined. The data analysis revealed a generally good ecological status of the habitat with high plant diversity. However, at the different juniper stands, subpopulations present high variability and face different problems, such as poor tree density, reduced numbers of juvenile trees or poor seed production, inadequate male:female ratios, a small number of female trees, reduced numbers of seeds with viable embryos, competition with other woody species, grazing, and illegal logging. From the results, the need for site-specific active management and interventions is demonstrated in order to preserve or achieve the good status of the habitat at all stands in the region.
\end{abstract}

Keywords: juniper; subpopulations; reproductive dynamics; spatial distribution; seed production; tree density; seed productivity; ecological evaluation

\section{Introduction}

The Mediterranean Basin is one of 34 world biodiversity hotspots [1-3]. Ecosystem profiles have pointed out that the unique climate and habitat heterogeneity found in the Mediterranean Basin, together with historical factors and differentiation of the flora itself, have resulted in the region's floristic richness. Among the European countries belonging to this region, Greece is one of the most species-rich, with more than 7000 native plant taxa, of which $20 \%$ are endemic [4-7].

Juniperus L. 1753 is a genus of conifers belonging to the family Cupressaceae. The genus Juniperus consists of up to 68 species around the world [8,9]. J. foetidissima Willd. 1806, known as stinking juniper, is like all species of the Juniperus genus, an aromatic, droughtresistant, bioecious, wind-pollinated, evergreen plant. Adult trees are medium-sized and 6-25 $\mathrm{m}$ high, with a stem diameter up to $2.5 \mathrm{~m}$ and two forms of leaves $[9,10]$. In the past, its wood was used in furniture manufacturing and more rarely as firewood [11].

The juniper populations in Europe are declining in size and number, e.g., in Belgium, the Netherlands, northern and western Germany, England, and the Mediterranean mountains [12-14]. Specifically, in the Mediterranean, summer drought seems to be a key factor for low regeneration in junipers [13,15], which is also constrained by the limited availability of suitable sites, the greatly reduced seed viability due to seed abortion and predation [16,17], and by wildfires and clearances [18]. Doğan et al. [19] mention a significant decrease in forest areas occupied by juniper forests (J. excelsa M. Bieb. 1798 and J. foetidissima) in Turkey. However, the northern juniper sites in Europe (subarctic populations) 
grow in more favorable environments, with fewer and less intensive limiting factors [17], presenting good regeneration e.g., in the Alps, Scandinavia, and Poland [20-22].

In Greece, eight species of junipers are found: J. communis L. 1753, J. drupacea Labill. 1791, J. excelsa, J. foetidissima, J. macrocarpa Sm. in Sibth. \& Sm. 1816, J. oxycedrus L. 1753, J. phoenicea L. 1753, and J. sabina L. $1753[5,23,24]$. J. foetidissima is more abundant than other Juniperus species, and forms a significant population in several Greek mountains $[25,26]$. From the dynamic view, J. foetidissima forests should be considered as a disadvantageous evolution of fir forests, where the fir holds a significant presence in its communities [25,27-29].

J. foetidissima trees form pure or open forests, and can also be found to grow as individuals within other formations dominated by Juniperus, Cedrus Trew 1757, Abies Mill. 1754, Pinus L. 1753, Phillyrea L. 1753, or Quercus L. 1753 species [19,30]. The J. foetidissima species is spreading in southeast and east Europe, Caucasus, and West and Central Asia [11,31,32] at altitudes from 700 to $2000 \mathrm{~m}$ a.s.l., mainly above shallow rocky soils [11]. Even though, according to the IUCN Red List of Threatened Species, Juniperus spp. is consider as a "least concern" and not globally threatened [11], Juniperus is listed as a priority habitat by the European Union $[11,33,34]$. J. foetidissima is protected in several areas of the world, either as forests, forest stands, habitats formations, or even as individual large trees $[11,35]$.

The ecological status evaluation of the juniper woodlands and information about their distribution, size structure, sex, health status, regeneration, and seed germination are key factors for their conservation, but the research on juniper forests status is, in general, limited. Even more limited worldwide is the research concerning J. foetidissima, focused on the species' essential oil characteristics [36-39]. However, in the last few years, the research has been extended, and scientific programs are being implemented in the Mediterranean, focusing on ways to prevent the further degradation of juniper woodlands (mainly in protected Natura 2000 sites) and to improve the ecological status of the populations. Indicatively, LIFE+ Nature Projects, funded by the EU, are or were implemented in Greece (e.g., Junicoast in Crete and the South Aegean Sea [40], JunEx in Prespes [41], and ForOpenForests in Mt. Oiti [42]), in Spain (Juniperus Tenerife in the Canary Islands [43]), in Cyprus (Junipercy [44]), etc., which include actions for the study and conservation of juniper priority habitats.

The main threats for J. foetidissima populations, according to the IUCN [11], are ecosystem degradation and conversion, reduced reproductive success, and species mortality induced by grazing, farming, and wildfires [11]. Research findings indicate that juniper woodlands are predicted to face decline in the future $[13,45]$. In many regions, junipers are already facing threats by drought, climate change, urban development, recreational activities, and commercial uses [46], or even by quarantine pathogens [47]. They are near threatened in central Asia [45,48] and endangered in Oman, with very low regeneration [49] and germination rates [45]. In the Canary Islands, juniper woodlands' degradation is occurring due to human activities [50]. Reduction of the stock density of junipers due to logging, clear cutting, overgrazing, soil erosion, and recreational activities is also addressed by other researchers $[45,51]$.

Drought and heat stress endorsed by climate change were identified as causes of forest mortality worldwide [52,53]. Climate change is found to affect tree phenology [54]. However, De Vries et al. [55] mention that the climate change effect on long-lived trees (like J. foetidissima) is difficult to predict, since they are affected by changes in species competition and pest and diseases dynamics. Climate change, mainly due to precipitation decrease and/or temperature increase, also affects the competition between plant species, limits seed dispersal, and enhances pathogens, leading to density reduction [46,56-58]. Gruwez et al. [59] address the issue of climate warming impact on the reduction of seed viability of junipers. According to Al Haddabi and Victor [45] and Maclaren [60], the already-occurring climate change will result in not only a general decrease in vegetation density, but also a significant possibility for juniper's extinction in Oman within the next few decades. 
Mt. Oiti has a complex hydrogeology, which, together with rare geomorphology, create sinkholes, deep gorges, caverns, springs, seasonal ponds, and rivers. It is characterized by unique flora, fauna, and other forms of life, some of them rare, and it is the southern-most distribution limit of several plant species, like Caltha palustris L. 1753 and Trollius europaeus L. 1753. Moreover, it is important for biodiversity at the European level, and, for this reason, it has been designated as a European Council Biogenetic Reserve. A total of 13 habitat types of Annex I Dir. 92/43/EEC have been recorded on the site, and four of them are priority ones $\left(3170^{*}, 6230^{*}, 9530^{*}, 9560^{*}\right)$ including junipers [34].

In this study, the ecological status of the J. foetidissima marginal population on the Natura 2000 site of Mt. Oiti in central Greece was assessed by processing distribution, size, structure, sex, age, and regeneration data of the habitat $\left(9560^{*}\right.$ endemic forests with Juniperus spp.), performing a general evaluation based on scarce measurements of the tree density, female tree density, seed productivity, and the percentage of juvenile trees in each stand. The results could be useful for the overall assessment of the ecological status of the specific priority habitat, and also for identifying the stand-specific characteristics within the site of Mt. Oiti, which require the implementation of different management interventions in order to be sustained, both in terms of conservation and restoration.

\section{Study Site and Methods}

\subsection{Study Site}

Mt. Oiti is a mountain of high ecological importance, which, however, belongs to the less explored areas of Greece [28]. The area is extended between latitudes $38^{\circ} 5^{\prime} 21.12^{\prime \prime} \mathrm{N}$ and $38^{\circ} 52^{\prime} 28.887^{\prime \prime} \mathrm{N}$ and longitudes $22^{\circ} 13^{\prime} 30.68^{\prime \prime} \mathrm{E}$ and $22^{\circ} 21^{\prime} 49.46^{\prime \prime} \mathrm{E}$ in central Greece, and was declared as the National Park of Mt. Oiti in 1966 by Royal Decree N.218 (published in Greek Government Gazette 56/12.3.1966). It is a Natura 2000 site (Figure 1), protected by the EU as a SCI (GR2440004), SPA (GR2440007), and IBA (GR 104) region. Its total area is about $7000 \mathrm{ha}$, consisting of the core strict nature protection zone (3370 ha) and the peripheral zone (3630 ha).

The vegetation of Mt. Oiti mainly includes Abies cephalonica Loudon 1838 forests, covering appr. 50\% of the whole mountain. Another significant presence is that of Quercus frainetto Ten. 1813 forests, together with mixed fir and oak ones, mostly in the southern and western parts of the area. It should also be noted that high altitude grasslands and rocky pastures cover approximately $10 \%$ of the study area [61].

The priority habitat $9560^{*}$ with J. foetidissima in Mt. Oiti is presented as marginal and a successor to the upper limits of the fir range $[27,28,62]$. It grows on limestone substrates, where the soil appears strongly eroded and degraded, usually with a horizon rich in organic matter. The presence of the habitat was confirmed at 10 locations inside the protected zone of Mt. Oiti (Figure 1). The habitat is referred under the code 5210 "Arborescent matorral with Juniperus spp.", described as "Mediterranean and sub-Mediterranean evergreen sclerophyllous scrub organized around arborescent junipers", sub-type 32.133, "J. excelsa and J. foetidissima arborescent matorrals", and described as "Arborescent matorrals of Greece, Anatolia and the Near East, dominated by J. excelsa or J. foetidissima", according to The Interpretation Manual of European Union Habitats-EUR28, which was adopted in order to help clear any ambiguities in the interpretation of the Annex 192/43/EEC [33].

The climate of the region is a Mediterranean type, characterized by a dry period of about four months beginning in mid-May and ending in mid-September, according to the pluvio-thermic diagram of the region (Figure 2). From the data recorded at the nearest meteorological station of Agathonos Monastery $\left(38^{\circ} 52^{\prime} 2^{\prime \prime} \mathrm{N}, 22^{\circ} 12^{\prime} 16^{\prime \prime} \mathrm{E}\right.$, alt. $533 \mathrm{~m}$ ), during the time period 1994-2004, the average annual air temperature in the region is $13.7^{\circ} \mathrm{C}$, varying from $5.5^{\circ} \mathrm{C}$ in winter to $23.5^{\circ} \mathrm{C}$ in summer. The hottest month of the year is July $\left(24.2^{\circ} \mathrm{C}\right)$, while December is the coldest $\left(5.8^{\circ} \mathrm{C}\right)$. The average annual precipitation is $790.2 \mathrm{~mm}$, distributed unevenly between seasons (336.1 mm in winter, $201.9 \mathrm{~mm}$ in spring, $59.0 \mathrm{~mm}$ in summer, $139.2 \mathrm{~mm}$ in autumn), while June is the driest month $(12.2 \mathrm{~mm})$ of the year. 


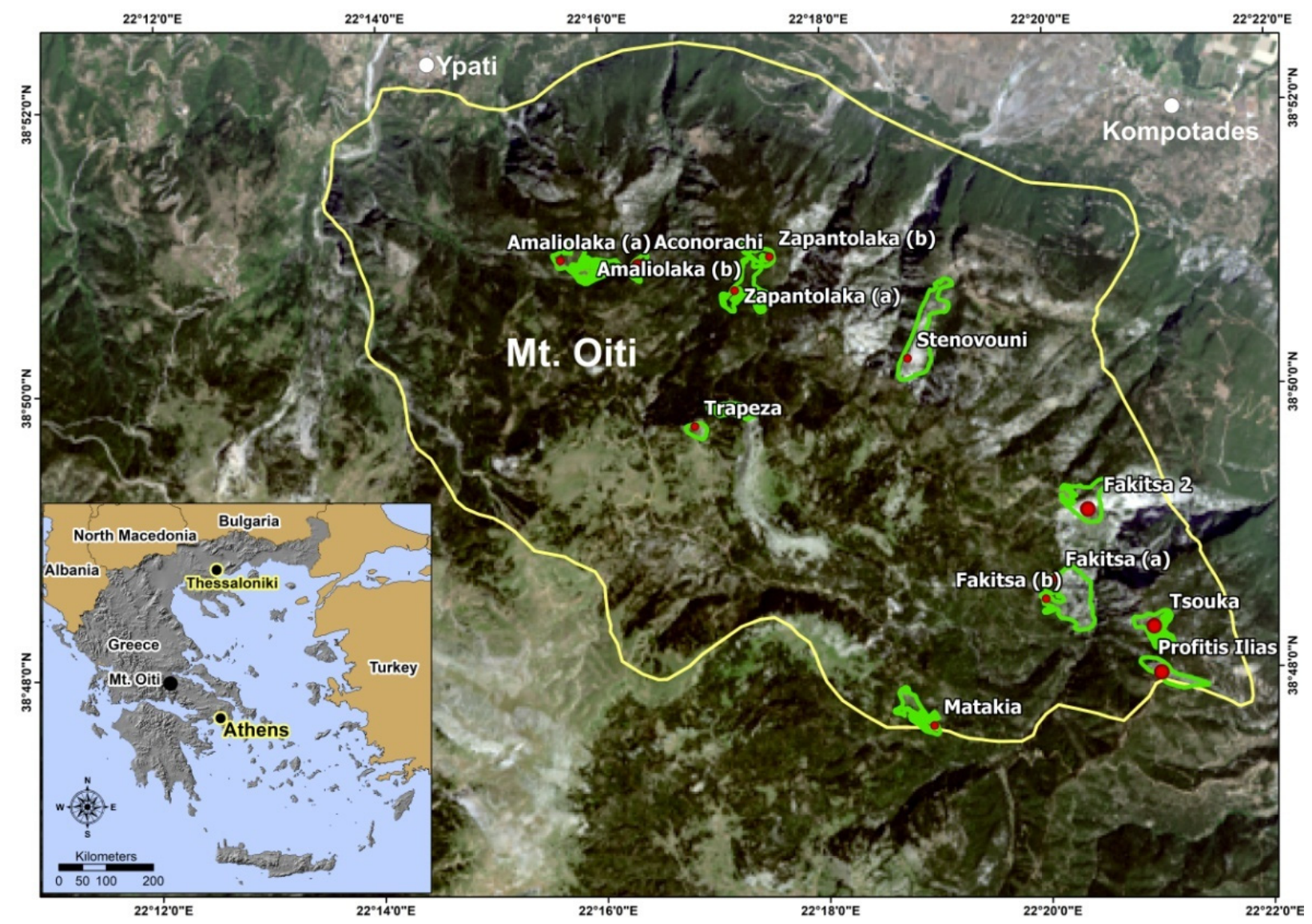

Figure 1. Map of the Greek National Park of Mt. Oiti depicting the border (yellow line) of the Natura 2000 site and the locations of the 12 study plots (Appendix A, Table A1) inside the 10 subpopulations of the J. foetidissima priority habitat 9560* (green polygons). Satellite image: Landsat 8 (channels 4, 3, 2 as RGB), acquisition date 30 August 2020.

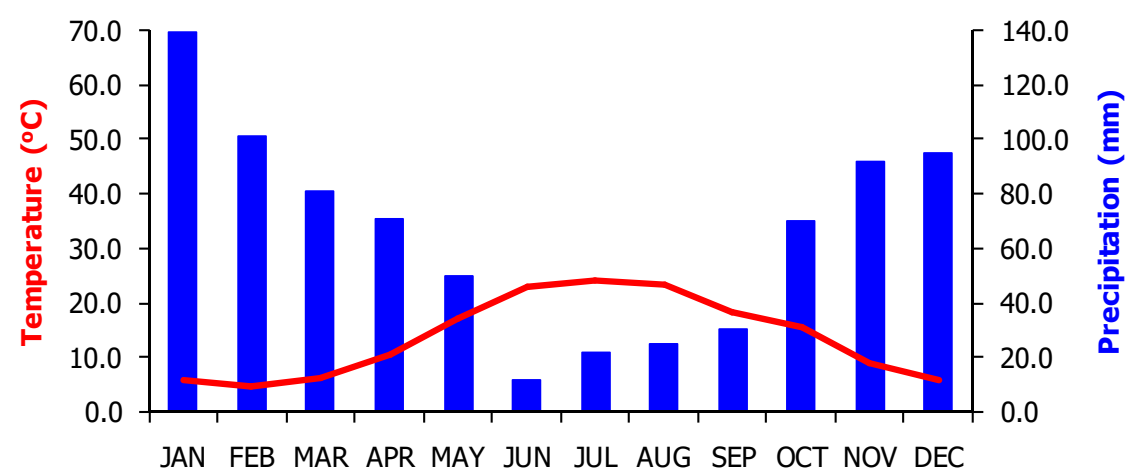

Month

Figure 2. Pluvio-thermic diagram derived from climatic data obtained from the meteorological station of Agathonos Monastery ( $38^{\circ} 52^{\prime} 2^{\prime \prime} \mathrm{N}, 22^{\circ} 12^{\prime} 16^{\prime \prime}$ E, alt. $533 \mathrm{~m}$ ) of the time period 1994-2004.

\subsection{Plot Design and Data Collection}

For studying the forest status of the J. foetidissima population in Mt. Oiti, biometric data were recorded. For the data collection, field trips were conducted during the years 2013, 2014, and 2015. A total of 10 forest stands of the species was identified within the NATURA 2000 core and peripheral zone, covering a total area of about 140 ha. Specifically, the presence of the habitat $9560^{*}$ with J. foetidissima was confirmed at 10 sites: "Fakitsa" (46 ha), “Trapeza" (7 ha), "Profitis Ilias" (10 ha), "Tsouka" (11 ha), "Matakia" (14 ha), "Zapantolaka" (12 and 7 ha), "Amaliolaka" (16 ha), "Aconorachi" (5 ha), and "Stenovouni" 
(19 ha) (see Figure 1). In each site, at least one representative plot of 0.1 ha was established (Appendix A, Table A1).

In each of the 12 established experimental plots, the exact positions of juniper trees were recorded, and measurements of diameter at breast height, tree height, population density, sex, geological substrate, soil characteristics, inclination and exposure, estimates of the reproductive effort, and age were also conducted. An additional number of trees outside the established plots was measured in order to enhance the reliability of the extracted results. In total, more than 1500 points of the trees, either isolated or within stands, were recorded with the use of a GPS devise in all locations where J. foetidissima was detected in order to map their expansion; 528 of these trees, all located inside the plots, were used as a sample in order to investigate the forest status at all regions within the Natura 2000 core zone. The rest of the trees, approx. 1000 outside the plots, were marked only for mapping the habitat, following at least five transects around each plot. Additionally, tree cores were extracted to determine the tree age.

For the reproductive status assessment, female cones were randomly collected by hand from all plots and from different parts of the trees (higher and lower parts of the canopy and at different aspects). From 1015 berries, the seeds were extracted by hand and the embryos were examined by eye in order to determine the number of seeds per cone and the percentage of full seeds with present alive (not dried) embryos.

\subsection{Data Analysis}

For the estimation of age and growth rates of $J$. foetidissima trees in each plot, the trees were categorized into seven groups of diameter $(<10 \mathrm{~cm}, 10-20 \mathrm{~cm}, 20-30 \mathrm{~cm}, 30-40 \mathrm{~cm}$, $40-50 \mathrm{~cm}, 50-60 \mathrm{~cm},>60 \mathrm{~cm})$ and six groups of height $(<2 \mathrm{~m}, 2-4 \mathrm{~m}, 4-6 \mathrm{~m}, 6-8 \mathrm{~m}, 8-10 \mathrm{~m}$, $>10 \mathrm{~m}$ ). From each diameter category, an increment core from a representative tree at each plot was taken for analysis for the age confirmation. Tree cores were not taken from young trees with diameters less than $10 \mathrm{~cm}$. Thus, a total number of 54 tree cores were extracted at breast height, and annual tree rings were counted. The ages of the trees were estimated using the tree height and breast diameter, along with the annual ring data taken in each plot.

For determining the sex of the trees, four categories were occupied: (a) males for trees bearing cones, (b) females for trees bearing berries (female cones), (c) ambisexual for trees bearing both male cones and female berries, and (d) not determined for trees bearing neither cones nor berries.

The female trees' cone coverage was estimated by eye $[45,63]$ using a three-point scale $(1,2,3)$, with 1 representing low, 2 moderate, and 3 abundant coverage. A representative female tree of the moderate category (2) was used as an index tree in order to estimate the number of seeds per female reproductive tree and per area unit within each plot. All berries from this index tree were collected and counted. The following assumptions were adopted: (a) all berries of the tree (1727) were uniformly distributed at the trees' foliage surface, (b) the juniper trees' crown shape was similar to that of a cone, so the foliage surface was equal to $\pi \mathrm{r}\left(\mathrm{r}^{2}+\mathrm{h}^{2}\right)^{0.5}$, where $\mathrm{h}$ represents the tree height and $\mathrm{r}$ the radius of the cone's base, which was estimated to be about one-third of the tree's height (Figure 3), and (c) the trees belonging to the low female cone coverage category (category 1) had 50\% less berries than those of the moderate category (category 2), while the trees belonging at the abundant category (category 3 ) carried 50\% more.

The similarities and dissimilarities between the junipers' subpopulations were investigated by applying a hierarchical analysis (dendrogram using Ward linkage) based on four critical parameters: (a) tree density, (b) female tree density, (c) estimated seed production per surface unit, and (d) the percentage of young trees with dbh less than $10 \mathrm{~cm}$. The IBM SPSS Statistics package version 23 was used for conducting the statistical analysis [64].

A trend analysis was performed in order to assess current climate changes by using long series data (1973-2010) from the near, though altitudinal lower, station of Lamia (lat. 38.9, long. 22.4, Alt. $144 \mathrm{~m}$ ), established by the Hellenic National Meteorological 
Service. The trends and their statistical significance were calculated with the Mann-Kendall test $[65,66]$ for different confidence levels, and the linear slopes were estimated by using the non-parametric Sen's slope method $[67,68]$.

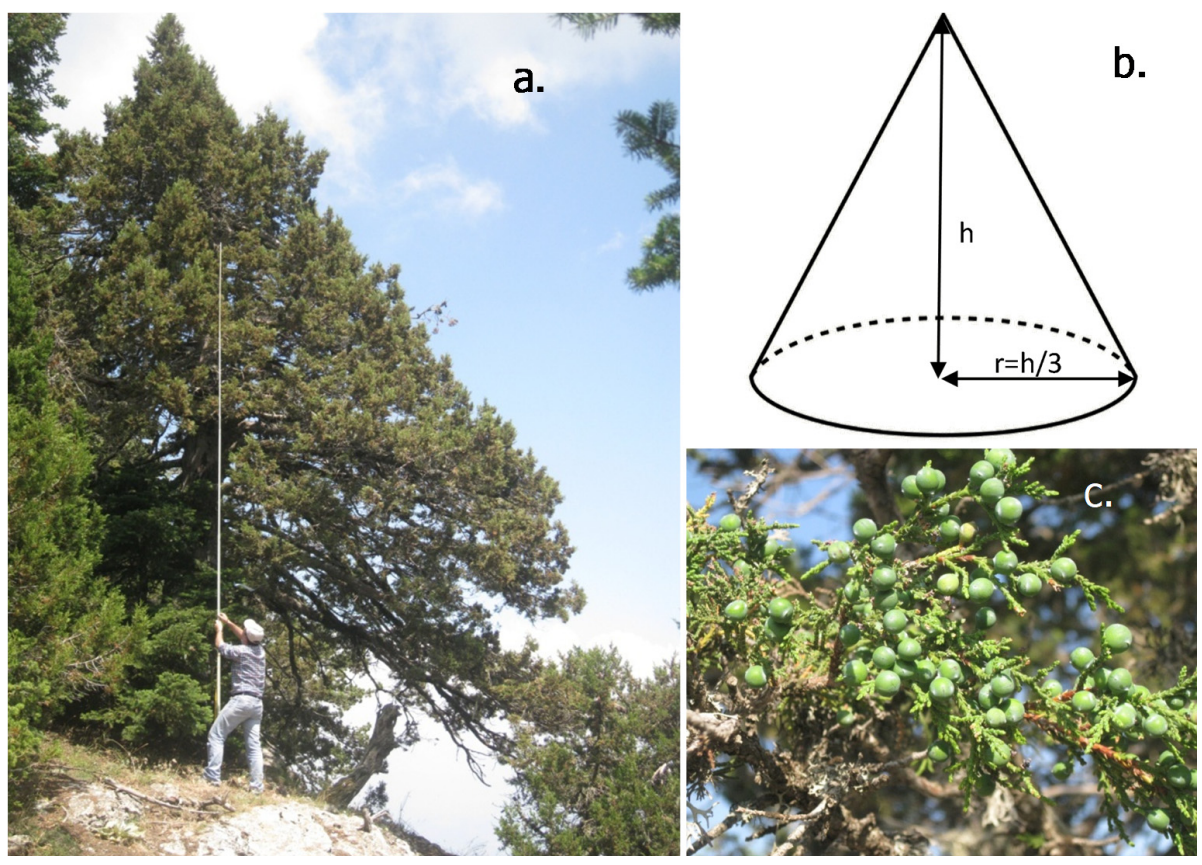

Figure 3. The shape of a J. foetidissima tree in Mt. Oiti (a) was considered as a cone with height $\mathrm{h}$ and radius $r$ of the cone base equal to $r=h / 3(b)$, for estimating the coverage with female berries (c).

\section{Results and Discussion}

\subsection{Climate Change Trends}

Since 1900, the climatic conditions in the region have become more arid [69]. The trend analysis was performed for the annual values of minimum, maximum, and average air temperature, and also for the annual precipitation. Significant changes were detected for the maximum $(Z=3.44, p<0.05)$ and average $(Z=2.07, p<0.001)$ temperature values, while the changes in minimum temperature and precipitation were not significant. Both average and maximum temperatures have been increasing since 1973, with rates $0.36^{\circ} \mathrm{C}$ and $0.46^{\circ} \mathrm{C}$ per decade, respectively. Such a climatic pattern in the region is expected to affect the current local distribution and ecological status of the J. foetidissima population. If the identified trends persist in the future, it is possible that this will lead to changes in the species expansion, especially at its lower altitudinal ranges, considering also the strong impact of meteorological variations and drought episodes on tree growth rates $[70,71]$.

\subsection{Subpopulations Distribution and Density}

J. foetidissima populations in Mt. Oiti are presented as rather small patches (with areas varying from 5 ha in "Aconorachi" to 46 ha in "Fakitsa"), covering a total area of about 140 ha and distributed randomly in the core and the peripheral zone of the Natura 2000 site. It seems that the protection of the site induced the total lack of vegetation management, thus resulting in a great expansion of the A. cephalonica forest and increasing the competition with the J. foetidissima stands, which kept their distribution to less fertile rocky soils with small soil depths. This pattern is not expected to be stable within the next few decades, since $A$. cephalonica individuals are expanded quickly, threatening the presence of other species, including junipers. The competition of juniper populations with other woody species (mainly J. phoenicea and Pinus brutia Ten. 1811-1815) is also underlined by Thanos et al. [72] for J. macrocarpa in Greece, who acknowledge pines as a considerable threat for juniper habitats due to higher rates in growth, increased seed production, easily 
germinable seeds, and soil modifications induced by the deposition of pine needles. It should be noted, however, that pines have a much higher dispersion rate than firs given their smaller seeds and their opportunistic nature, whereas J. foetidissima is a long-lived species. These factors indicate that the impact of fir expansion in Mt. Oiti is expected to be less intense compared to other juniper species competing with pines.

The average density is $190( \pm 13.9)$ trees per ha, but with great variability between plots, from 30 in "Trapeza" and "Amaliolaka (b)" to 417 in "Amaliolaka (a)". However, such densities are considered rather high compared to other juniper species in other areas. More specifically, Gardner and Fisher [73] found that junipers in Oman (J. seravschanica Kom. 1932) formed woodlands with a maximum density of 150 trees/ha, whereas $\mathrm{Al}$ Haddabi and Victor [45] mentioned for the same region 20 years later that tree densities varied between different zones from $14.56( \pm 2.29)$ to $21.7( \pm 2.85)$ due to soil degradation (erosion) induced by human activities. Furthermore, Thanos et al. [72] mentioned densities varying from 43 to 145 trees per ha for J. macrocarpa in Greece.

\subsection{Trees Size and Structure}

In general, juniper trees on Mt. Oiti are distributed in all height categories, though with small height trees dominating. The tree heights in the region are only indicative of the trees' age, since the site is suffering from extensive illegal logging of the tree branches (main or lateral limbs), thus affecting their heights. About $49 \%$ of the total number of trees had heights less than $4 \mathrm{~m}$, while $30 \%$ less than $2 \mathrm{~m}$. Adult individuals with heights between 4 to $10 \mathrm{~m}$ represented $47 \%$ of the total sample, and very high trees with heights above $10 \mathrm{~m}$ represented $4 \%$. This pattern indicates that the population dynamics are, in general, in good status, with all tree classes represented and short (young) trees dominating, while adults and very high (old) trees were also found in adequate percentages. However, this general pattern differed among juniper subpopulations, presenting great variability. The tree distribution per height category in each plot is shown in Figure 4. In some plots (e.g., "Amaliolaka (a)", "Fakitsa (a) and (b)", and "Stenovouni"), short trees with heights less than $2 \mathrm{~m}$ were dominating, while in others, they were in very low percentages (e.g., "Trapeza", "Profitis Ilias", and "Zapantolaka (a)") or even totally absent (e.g., "Zapantolaka (b)", "Matakia" and "Amaliolaka (a)"). Very high trees with heights above $10 \mathrm{~m}$ were totally absent (at seven of 12 plots) or rare (at three of 12 plots) at most plots, while in "Zapantolaka (b) and (a)" they represented a significant percentage (14\%) or even dominated (55\%) the local subpopulations.

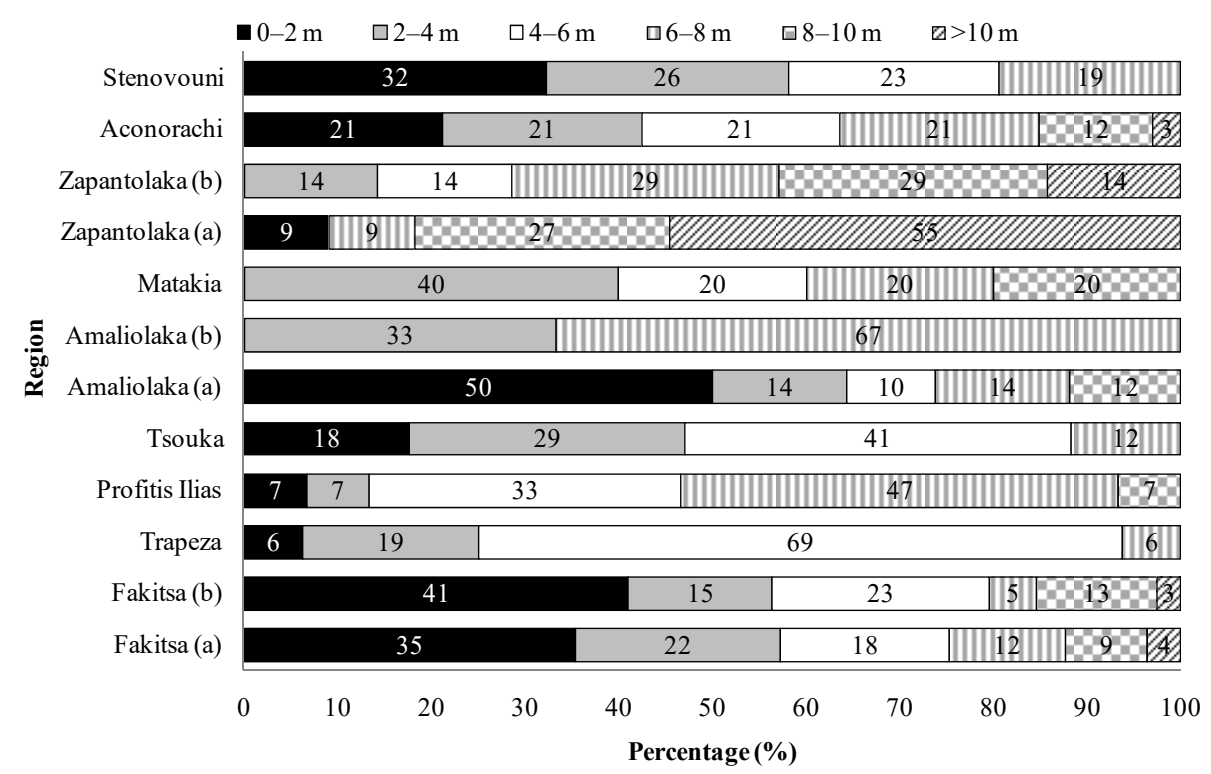

Figure 4. Percentage distribution of J. foetidissima trees to height classes at different regions of the study area. 
The diameter at breast height ( $\mathrm{dbh}$ ) is a more adequate measure for studying the status of tree sizes compared to height, mainly due to branch logging from the trees in the study area. However, dbh correlated well with the tree height, as shown in Figure 5 (linear correlation: $\mathrm{dbh}=6.519$, height-9.096, $\mathrm{R}^{2}=0.542$ ). Additionally, the trees' ages were better correlated with dbh than height (age $=1.75, \mathrm{dbh}=1.094, \mathrm{R}^{2}=0.492$ ).

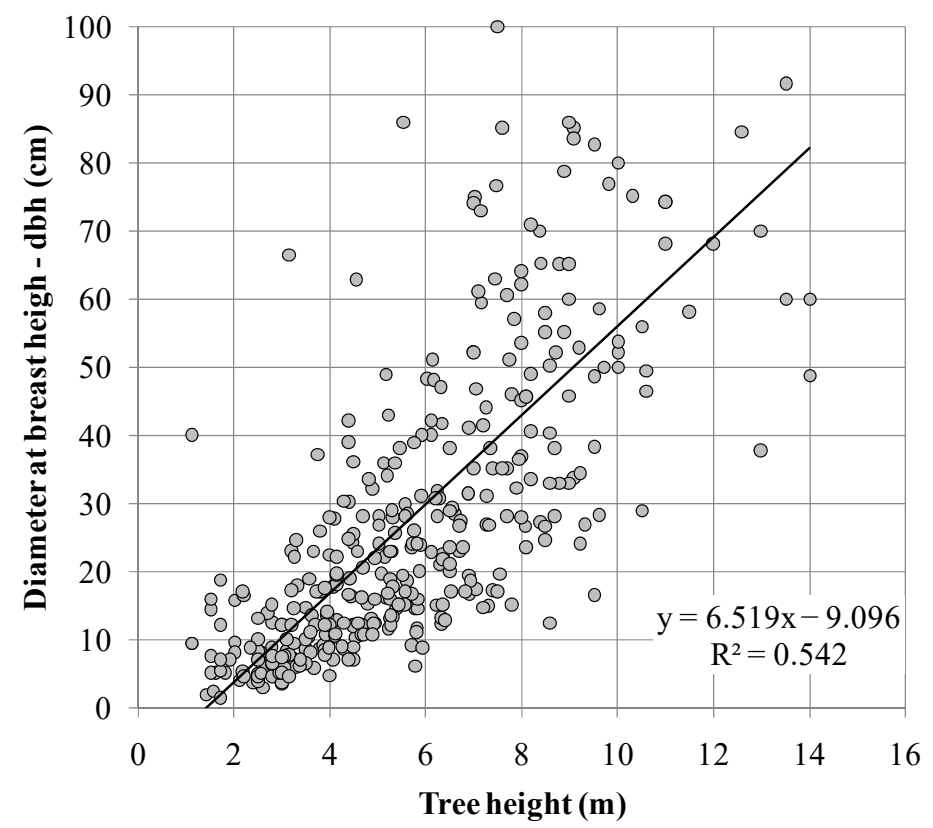

Figure 5. The diameter at breast height $(\mathrm{dbh})$ linear correlation with tree heights of $J$. foetidissima trees in Mt. Oiti.

In general, the juniper population in the study area consisted mainly (30.4\%) of trees with a dbh less than $10 \mathrm{~cm}$, while very large trees with a dbh above $60 \mathrm{~cm}$ represented $12 \%$. This average distribution is highly varied among different juniper subpopulations within the plots (Figure 6). Young trees with a small dbh (bellow $10 \mathrm{~cm}$ ) dominated (e.g., by $62 \%$ in "Amaliolaka", 55\% in "Fakitsa (a)", and 54\% "Fakitsa (b)") or constituted significant percentages (e.g., 42\% in "Stenovouni", 40\% in "Matakia", 33\% in "Akonorachi" and "Amaliolaka (b)", and 24\% in "Tsouka"), while in others had low percentages (e.g., 13\% in "Trapeza" and 9\% in "Zapantolaka (a)") or even zero percentages (e.g., "Zapantolaka (b)" and "Profitis Ilias"). On the other hand, very large trees with a dbh above $60 \mathrm{~cm}$ also differed among areas, dominating in "Profitis Ilias" (55\%) or even being absent in "Trapeza", "Zapantolaka (b)", and "Amaliolaka (b)". The highly varied juvenile representation is also recorded for other juniper species in Greece, e.g., Thanos et al. [72] found percentages of young J. macrocarpa trees varying from almost zero to $38.6 \%$. Multi-stem trees are relatively rare in the region. About $10 \%$ had two stems per tree, and only $1 \%$ had more than five. A high percentage (about $82 \%$ ) were single-stemmed.

\subsection{Tree Sex and Reproductive Dynamics}

For most of the examined trees, the sex was not definable, since they had neither female berries nor male cones. They were mainly young, and thus not reproductive individuals, or trees poor in health and not reproductively active. In $61.7 \%$ of the cases, trees were characterized as not determined in terms of their sex definition. Male individuals baring cones were $19.7 \%$, and $18.6 \%$ were females bearing berries. The male and female trees had slight morphological differences. The female individuals were slightly higher with a greater dbh compared to the male ones, while they had no differences concerning their numbers of stems. 


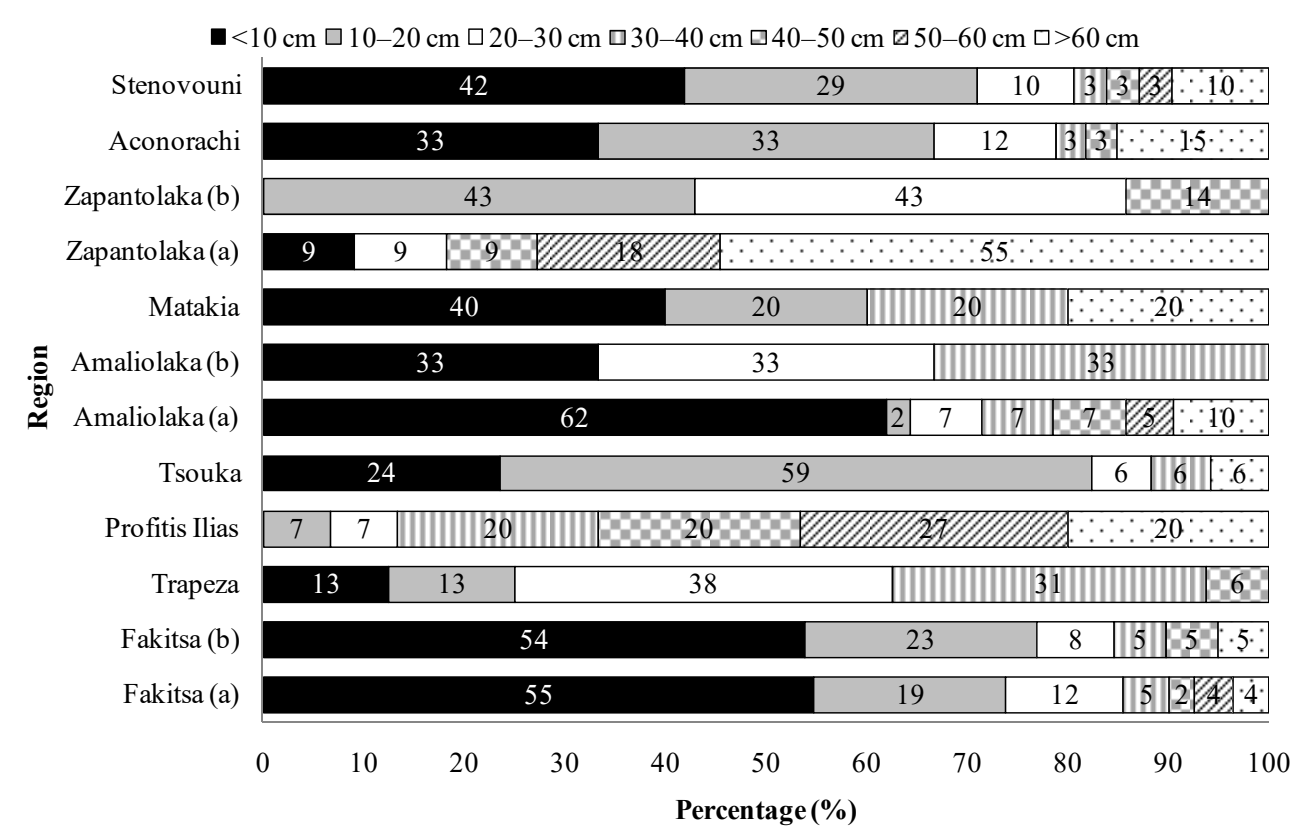

Figure 6. The percentage distribution of J. foetidissima trees according to dbh classes at different regions of the study area.

The average male to female ratio was slightly male-biased at 1.2, though differed significantly among the different regions. In five of 12 plots ("Amaliolaka (a)", "Profitis Ilias", "Stenovouni", and "Fakitsa (a) and (b)"), males dominated with male to female ratios ranging from 1.4 to 3.3, while three plots ("Aconorachi", "Zapantolaka (a)", and "Trapeza") were dominated by females with male to female ratios between 0.4 and 0.7. However, there were four regions ("Amaliolaka (b)", "Zapantolaka (b), "Matakia", and "Tsouka") where the two sexes were equally balanced. Additionally, only one ambisexual individual was found, which had mainly male cones and only a couple of female berries. The variance of the male to female ratio, even at the same region, is also discussed by $\mathrm{Al}$ Haddabi and Victor [45] for juniper species (J. seravschanica) in Oman. In their study, even though females were dominant at most of the plots they examined, they also found that the ambisexual individuals were rare (about $5 \%$ ), and those trees had mainly male cones and a few female berries. Furthermore, Thanos et al. (2010) for J. macrocarpa subpopulations in Greece mentioned the dominance of male individuals at two of the seven plots they studied, while in the others, the male to female ratio varied between 0.97 and 1.12.

The average female tree density in Mt. Oiti was 37 trees per ha, but varied between plots, from about 10 in "Tsouka", "Amaliolaka (b)", "Zapantolaka (b)", and "Matakia" to 90 in "Aconorachi". The female cone coverage was low for $43 \%$, moderate for $37 \%$, and abundant for $20 \%$ of the examined female trees. The estimated average number of female cones produced per ha was 310 thousand, greatly varying among plots, from 60 thousand in "Amaliolaka (b)" to 862 thousand in "Zapantolaka (a)". These findings are in line with the estimated cone production of 20 cones per $\mathrm{m}^{2}$ in J. macrocarpa subpopulations in Greece [72].

The number of seeds per cone was on average 2.54 , but with a variability of $1-4$ seeds per cone. Most berries carried two $(46.50 \%)$ or three $(44.75 \%)$ seeds and rarely one or four seeds $(2.50 \%$ and $6.00 \%$, respectively). Furthermore, an insignificant percentage of $0.25 \%$ was found with no seeds. Most of the produced seeds were empty, and only a small percentage of $3.45 \%$ were full with present, not dried embryos. This is consistent with the findings of Al Haddabi and Victor [45], who reported that a large number of seeds produced by junipers is not viable, because of birds, rodents, soil erosion [74], and embryo abortion. Chambers et al. [75] also associated the low seed production in junipers with high levels of pre-dispersal seed predation and extensive seed abortion. The issue of embryos' viability is quite important for the Mediterranean region, and it is also addressed by 
García et al. [17], who found high variability of the number of seeds per cone of J. communis and that the filled seeds were less in the Mediterranean high mountains compared to other European regions due to seed abortion and predation, leading to important limitations in the natural regeneration of the juniper species $[8,13,76-78]$. The juniper populations in Spain were also found to have lower fertility than in the northern ecosystems [79-82]. In Greece, Thanos et al. [72] mentioned low percentages of live embryos and low germination rates of J. macrocarpa.

\section{Evaluation of J. foetidissima Ecological Status in Mt. Oiti}

In general, juniper subpopulations in the study area are in good status. The averages of trees and female tree densities are 190 and 37 trees per ha, respectively, indicating that J. foetidissima in Mt. Oiti forms relatively dense stands. The regeneration dynamics are also considered as adequate, with an estimated average seed production of 790 thousand seeds per ha and a young tree percentage of about $30.4 \%$ on average. However, this general pattern is highly variable between different populations. Thus, there are sites where necessary measures must be undertaken in order to improve the status of the juniper stands. Specifically, seven of the 12 plots ("Trapeza", "Profitis Ilias", "Tsouka", "Amaliolaka (b)", "Matakia", and "Zapantolaka (a) and (b)") have similar (Figure 7a) low (below average) tree density, while five of them (except for Zapantolaka (a) and Profitis Ilias") have also similar (Figure 7b) low female tree density. Some sites, such as "Trapeza", "Profitis Ilias", "Tsouka", and "Zapantolaka (a) and (b)", suffer from low regeneration with low percentages of younger individuals (presenting similarities, Figure 7d), while most ("Trapeza", "Profitis Ilias", "Tsouka", "Amaliolaka (a) and (b)", "Matakia", "Zapantolaka (b)", and "Stenovouni") have low seed production (Figure 7c). The overall assessment based on the subpopulation similarities in the tree density, presence of female trees, seed production, and presence of juveniles indicate that "Fakitsa (a) and (b)", "Zapantolaka (a)", and "Aconorachi" are significantly dissimilar compared to the other subpopulations, conforming two distinctive groups (Figure 7e). The sites of "Fakitsa (a) and (b)", "Profitsis Ilias", and "Tsouka" face threats from extensive illegal logging, while the more accessible sites of "Matakia", "Fakitsa (a) and (b)", "Amaliolaka (b)", "Zapantolaka (a)", "Tsouka", and "Trapeza" suffer from cattle grazing. Grazing and illegal cuttings were also identified by Milios et al. [83] as key factors in juniper forest degradation, even in protected areas in Greece.

Most of the sites (eight out of 12) are growing above degraded rocky soils from erosion, affecting the growth of juniper trees. Furthermore, in all plots, the expansion of A. cephalonica in the future is expected to increase the competition against J. foetidissima. This pattern affects not only the species growth rates and expansion, but also the flora composition of the habitat. It is known that even the degraded juniper woodlands are characterized by outstanding plant species diversity e.g., [50]. In Mt. Oiti, the plant species composition of the J. foetidissima woodlands includes a bushy floor with a height of 4-5 m, having an average coverage of about $40 \%$ and not exceeding $60 \%$ and consisting of the following woody plant species: A. cephalonica, Athyrium filix-femina (L.) Roth 1799, Daphne oleoides Schreb. 1766, Fraxinus ornus L. 1753, J. foetidissima, Lonicera nummulariifolia Jaub. \& Spach 1843, and Rosa pulverulenta M. Bieb. 1808. Furthermore, the forest floor vegetation coverage does not exceed $60 \%$, with an average of about $40 \%$, consisting of a high number of plant species that may be categorized into two main categories: (a) plant species of Stipo-Morinion Quézel 1964 category (e.g., Achillea fraassii Sch. Bip. 1842, A. holosericea Sm. 1813, Aubrieta deltoidea (L.) DC. 1821, Cerastium candidissimum Correns 1909, Pterocephalus perennis DC. 1823 , etc.) found mainly in the core of J. foetidissima plant communities, where the species dominates [84], and (b) species of the steady sequence of fir (e.g., Arrhenatherum elatius (L.) J. Presl \& C. Presl 1819, Helictotrichon convolutum (C. Presl) Henrard 1940, Geocaryum capillifolium (Guss.) Coss. 1851, Silene multicaulis Guss. 1826, Teucrium chamaedrys L. 1753, etc.) in areas where clusters are mixed with firs [28,61]. It is noteworthy that the plants are of crucial importance, as they reduce erosion and help conserve the soil of the study area. 
Moreover, the plant species are the primary habitat for other organisms (e.g., they provide food, coverage, and shelter for the wildlife).

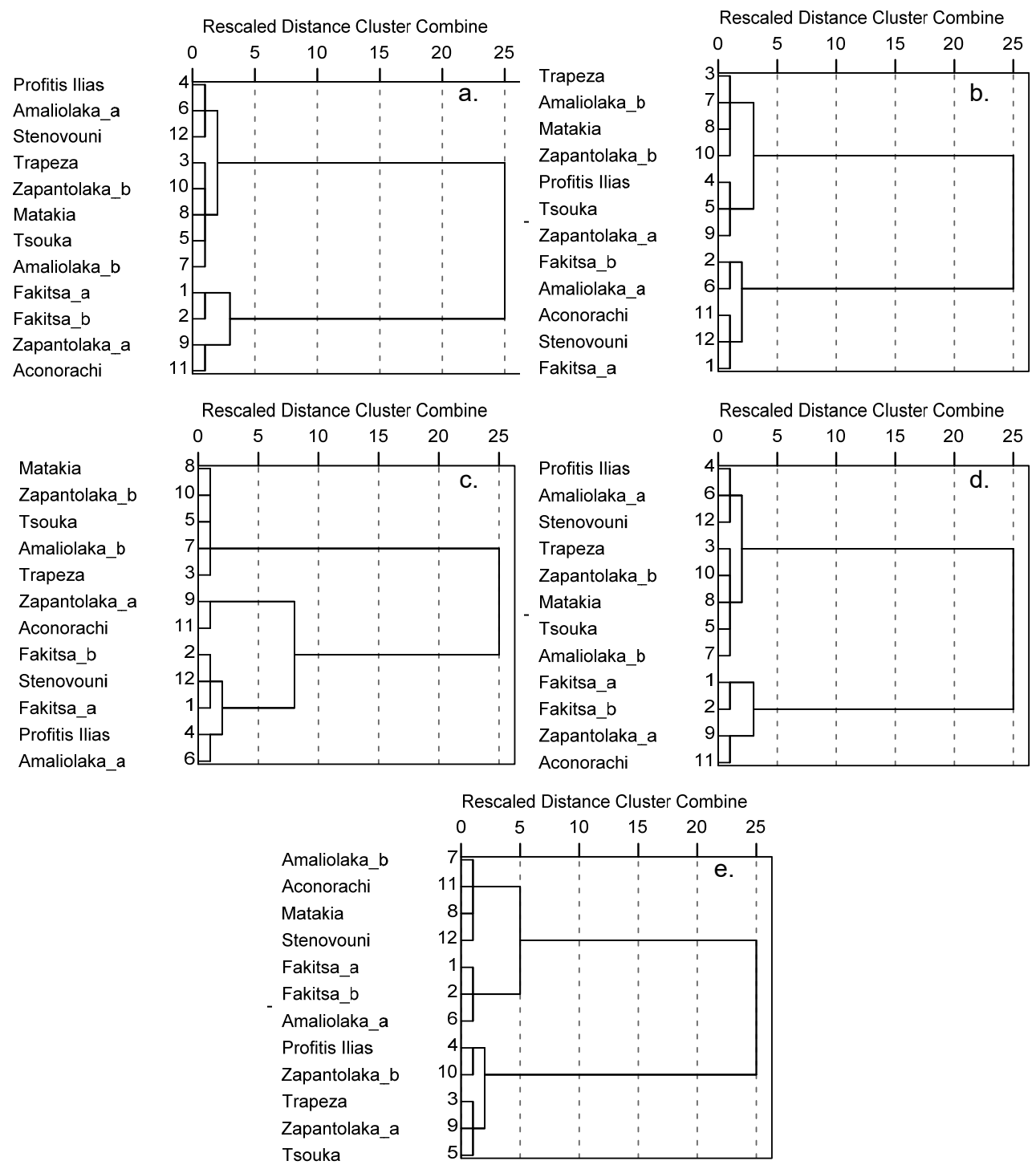

Figure 7. Dendrograms with Ward linkage for the J. foetidissima subpopulations in Mt. Oiti based on tree density (a), female tree density (b), estimated seed production per surface unit (c), percentage of young trees with a dbh less than $10 \mathrm{~cm}(\mathbf{d})$, and all the above mentioned parameters (e).

From the above information, it is concluded that different management interventions are necessary at different sites to establish the sustainability of juniper ecosystems. De Vries et al. [55] proposed active management focused on improving growth and reproduction, reducing competition and shortening regeneration time, moving populations from vulnerable areas to other areas with more favorable conditions, or creating a multiple population breeding system [85]. Furthermore, Milios et al. [83] suggested for J. excelsa in Greece forest management imitating grazing and illegal cuttings by the suppression of other species through periodic cuttings and avoidance of controlled grazing because of its impacts on soil degradation. However, the impact of grazing on the soil is critical for habitat conservation, and recently, Perrino et al. [86] proposed an innovative methodology with a grazing plan in protected areas. Additionally, Calaciura and Spinelli [87] proposed certain actions and useful tools for the conservation of junipers (habitat 5210 Arborescent matorral with Juniperus spp.), like controlled grazing aiming to moderate disturbances, mowing and periodic cuttings for maintaining more open space in order to preserve mator- 
rals threatened by invasion/competition, fire prevention actions, etc. The authors, however, acknowledge that overgrazing may have detrimental impacts, underlining the necessity for continuous monitoring of the habitats' ecological status and evaluation of the management action effectiveness.

Author Contributions: Conceptualization, N.P.; methodology, N.P. and G.K.; formal analysis, N.P.; investigation, N.P., A.S., G.K. and K.T.; resources, N.P., G.K., G.M., K.K., A.B. and G.L.; data curation, N.P.; writing—original draft preparation, N.P.; writing—review and editing, N.P., A.S., G.K., K.T. and G.L.; visualization, N.P.; supervision, N.P.; funding acquisition, G.K. All authors have read and agreed to the published version of the manuscript.

Funding: This research was co-funded by European Union (financial instrument LIFE+ Nature), grant number LIFE11 NAT/GR/1014, Project ForOpenForests: Conservation of priority forests and forest openings in Ethnikos Drymos Oitis and Oros Kallidromo of Sterea Ellada.

Data Availability Statement: Data available on request due to privacy restrictions.

Acknowledgments: Authors highly acknowledge the contribution of Emmanouil Psomiadis for the design of the map presented in Figure 1 and K. Ioannidis and S. Kassioti for the help in data collection and the field/laboratory work. We also thank the three anonymous reviewers and the academic editor for their thorough reviews and their insightful comments and suggestions. The authors wish to dedicate this work to the memory of our late colleague and friend Pinelopi Delipetrou, who passed away recently.

Conflicts of Interest: The authors declare no conflict of interest.

\section{Appendix A}

Table A1. Plots, names and geographical coordinates.

\begin{tabular}{ccc}
\hline Plot Name & Latitude Coordinates & Longitude Coordinates \\
\hline Aconorachi & $38^{\circ} 50^{\prime} 52.88^{\prime \prime} \mathrm{N}$ & $22^{\circ} 16^{\prime} 21.25^{\prime \prime} \mathrm{E}$ \\
Amaliolaka (a) & $38^{\circ} 50^{\prime} 55.49^{\prime \prime} \mathrm{N}$ & $22^{\circ} 15^{\prime} 38.62^{\prime \prime} \mathrm{E}$ \\
Amaliolaka (b) & $38^{\circ} 50^{\prime} 51.96^{\prime \prime} \mathrm{N}$ & $22^{\circ} 15^{\prime} 54.28^{\prime \prime} \mathrm{E}$ \\
Fakitsa (a) & $38^{\circ} 48^{\prime} 38.66^{\prime \prime} \mathrm{N}$ & $22^{\circ} 20^{\prime} 3.87^{\prime \prime} \mathrm{E}$ \\
Fakitsa (b) & $38^{\circ} 48^{\prime} 29.67^{\prime \prime} \mathrm{N}$ & $22^{\circ} 19^{\prime} 58.68^{\prime \prime} \mathrm{E}$ \\
Matakia & $38^{\circ} 47^{\prime} 36.96^{\prime \prime} \mathrm{N}$ & $22^{\circ} 18^{\prime} 57.22^{\prime \prime} \mathrm{E}$ \\
Profitis Ilias & $38^{\circ} 48^{\prime} 0.53^{\prime \prime} \mathrm{N}$ & $22^{\circ} 21^{\prime} 0.76^{\prime \prime} \mathrm{E}$ \\
Stenovouni & $38^{\circ} 50^{\prime} 12.28^{\prime \prime} \mathrm{N}$ & $22^{\circ} 18^{\prime} 45.76^{\prime \prime} \mathrm{E}$ \\
Trapeza & $38^{\circ} 49^{\prime} 44.65^{\prime \prime} \mathrm{N}$ & $22^{\circ} 16^{\prime} 50.47^{\prime \prime} \mathrm{E}$ \\
Tsouka & $38^{\circ} 48^{\prime} 19.24^{\prime \prime} \mathrm{N}$ & $22^{\circ} 20^{\prime} 56.60^{\prime \prime} \mathrm{E}$ \\
Zapantolaka (a) & $38^{\circ} 50^{\prime} 41.73^{\prime \prime} \mathrm{N}$ & $22^{\circ} 17^{\prime} 12.58^{\prime \prime} \mathrm{E}$ \\
Zapantolaka (b) & $38^{\circ} 50^{\prime} 55.85^{\prime \prime} \mathrm{N}$ & $22^{\circ} 17^{\prime} 31.62^{\prime \prime} \mathrm{E}$ \\
\hline
\end{tabular}

\section{References}

1. Cowling, R.M.; Rundel, P.W.; Lamont, B.B.; Arroyo, M.K.; Arianoutsou, M. Plant diversity in Mediterranean-climate regions. Trends Ecol. Evol. 1996, 11, 362-366. [CrossRef]

2. Davis, G.; Richardson, D. Mediterranean-Type Ecosystems. The Function of Biodiversity; Springer: Berlin/Heidelberg, Germany, 1995. [CrossRef]

3. Perrino, E.; Tomaselli, V.; Costa, R.; Pavone, P. Conservation status of habitats (Directive 92/43 EEC) of coastal and low hill belts in a Mediterranean biodiversity hot spot (Gargano-Italy). Plant Biosyst. Int. J. Deal. Asp. Plant Biol. 2013, 147, 1006-1028. [CrossRef]

4. Dimopoulos, P.; Raus, T.; Bergmeier, E.; Constantinidis, T.; Iatrou, G.; Kokkini, S.; Strid, A.; Tzanoudakis, D. Vascular Plants of Greece: An Annotated Checklist; Englera; Botanischer Garten und Botanisches Museum Berlin-Dahlem, Freie Universität Berlin: Berlin, Germany; Hellenic Botanical Society: Athens, Greece, 2013; Volume 31, pp. 1-370.

5. Dimopoulos, P.; Raus, T.; Bergmeier, E.; Constantinidis, T.; Iatrou, G.; Kokkini, S.; Strid, A.; Tzanoudakis, D. Vascular plants of Greece: An annotated checklist. Supplement. Willdenowia 2016, 46, 301-347. [CrossRef]

6. Kougioumoutzis, K.; Kokkoris, I.P.; Panitsa, M.; Kallimanis, A.; Strid, A.; Dimopoulos, P. Plant Endemism Centres and Biodiversity Hotspots in Greece. Biology 2021, 10, 72. [CrossRef] 
7. Solomou, A.D.; Sfougaris, A. Contribution of Agro-Environmental Factors to Yield and Plant Diversity of Olive Grove Ecosystems (Olea europaea L.) in the Mediterranean Landscape. Agronomy 2021, 11, 161. [CrossRef]

8. Hazubska-Przybył, T. Propagation of Juniper Species by Plant Tissue Culture: A Mini-Review. Forests 2019, 10, 1028. [CrossRef]

9. Kasaian, J.; Behravan, J.; Hassany, M.; Emami, S.; Shahriari, F.; Khayyat, M. Molecular characterization and RAPD analysis of Juniperus species from Iran. Genet. Mol. Res. GMR 2011, 10, 1069-1074. [CrossRef] [PubMed]

10. Ghasemnezhad, A.; Ghorbanzadeh, A.; Sarmast, M.K.; Ghorbanpour, M. A Review on Botanical, Phytochemical, and Pharmacological Characteristics of Iranian Junipers (Juniperus spp.). In Plant-Derived Bioactives; Springer: Berlin/Heidelberg, Germany, 2020; pp. 493-508. [CrossRef]

11. Farjon, A. Juniperus foetidissima. The IUCN Red List of Threatened Species 2013: E.T42234A2965043. Available online: https: / / www.iucnredlist.org/species/42234/2965043 (accessed on 13 March 2021).

12. Clifton, S.J.; Ward, L.K.; Ranner, D.S. The status of juniper Juniperus communis L. in northeast England. Biol. Conserv. 1997, 79, 67-77. [CrossRef]

13. García, D.; Zamora, R.; Hódar, J.A.; Gómez, J.M. Age structure of Juniperus communis L. in the Iberian peninsula: Conservation of remnant populations in Mediterranean mountains. Biol. Conserv. 1999, 87, 215-220. [CrossRef]

14. Oostermeijer, J.G.B.; De Knegt, B. Genetic population structure of the wind-pollinated, dioecious shrub Juniperus communis in fragmented Dutch heathlands. Plant Spec. Biol. 2004, 19, 175-184. [CrossRef]

15. García, D. Regeneración natural del enebro Juniperus communisL. In Áreas de Alta Montaña Mediterranea, Conectando la Ecología Reproductiva con el Reclutamiento Poblacional; Universidad de Granada: Granada, Spain, 1998.

16. Eriksson, O.; Ehrlén, J. Seed and microsite limitation of recruitment in plant populations. Oecologia 1992, 91, 360-364. [CrossRef] [PubMed]

17. García, D.; Zamora, R.; Gómez, J.M.; Jordano, P.; Hódar, J.A. Geographical variation in seed production, predation and abortion in Juniperus communis throughout its range in Europe. J. Ecol. 2000, 88, 435-446. [CrossRef]

18. Zamora, R.; Gómez, J.; García, D.; Hódar, J.A. Ecología reproductiva y regeneración del matorral de la alta montaña de Sierra Nevada: Capacidad de respuesta a las perturbaciones. In Sierra Nevada: Conservación y Desarrollo Sostenible; Rosúa, C., Ed.; Universidad de Granada: Granada, Spain, 1996; Volume 2, pp. 407-422.

19. Doğan, H.H.; Karadelev, M.; Işiloğlu, M. Macrofungal diversity associated with the scale-leaf juniper trees, Juniperus excelsa and J. foetidissima, distributed in Turkey. Turk. J. Bot. 2011, 35, 219-237. [CrossRef]

20. Faliński, J.B. Vegetation dynamics and sex structure of the populations of pioneer dioecious woody plants. Vegetatio 1980, 43 , 23-38. [CrossRef]

21. Rosén, E. Periodic droughts and long-term dynamics of alvar grassland vegetation on Öland, Sweden. Folia Geobot. 1995, 30, 131-140. [CrossRef]

22. Rosén, E.; Bakker, J.P. Effects of agri-environment schemes on scrub clearance, livestock grazing and plant diversity in a low-intensity farming system on Öland, Sweden. Basic Appl. Ecol. 2005, 6, 195-204. [CrossRef]

23. Arabatzis, T. Shrubs and Trees in Greece; Oikologiki Kinisi Dramas, Technological Educational Institute of Kavala: Drama, Greece, 1998; p. 292. ISBN 960-85951-2-6. (In Greek)

24. Korakis, G. Forest Botany (e-Book); Association of Greek Academic Libraries: Athens, Greece, 2015.

25. Barbero, M.; Quézel, P. Les groupements forestiers de Grèce centro-méridionale. Ecol. Mediterr. 1976, 2, 3-86. [CrossRef]

26. Quézel, P. Contribution a l' etude de la vegetation du Vardussia. Biol. Gallo Hell. 1973, 5, 139-166.

27. Dimopoulos, P. Floristic and Phytosociological Research on Mount Kilini: An Ecological Approach; University of Patras: Patras, Greece, 1993.

28. Karetsos, G. Study of the Ecology and Vegetation of Mount Iti. Ph.D. Thesis, University of Patras, Patras, Greece, 2002. (In Greek with English Summary)

29. Stara, K.; Tsiakiris, R.; Wong, J.L. Valuing trees in a changing cultural landscape: A case study from northwestern Greece. Hum. Ecol. 2015, 43, 153-167. [CrossRef]

30. Médail, F.; Monnet, A.-C.; Pavon, D.; Nikolic, T.; Dimopoulos, P.; Bacchetta, G.; Arroyo, J.; Barina, Z.; Albassatneh, M.C.; Domina, G. What is a tree in the Mediterranean Basin hotspot? A critical analysis. For. Ecosyst. 2019, 6, 1-19. [CrossRef]

31. Carus, S. Increment and Growth in Crimean Juniper (Juniperus excelsa Bieb.) Stands in Isparta-Siitciiler Region of Turkey. J. Biol. Sci. 2004, 4, 173-179. [CrossRef]

32. Davis, P.; Miller, R.; Tan, K. Flora of Turkey and the Aegean Islands. Vol. 1-9; Edinburg Universty Press: Edinburg, TX, USA, 1965.

33. European Commission. The Interpretation Manual of European Union Habitats-EUR28; Technical Report; European Commission, DG Environment, Nature ENV B.3: Brussels, Belgium, 2013; p. 146.

34. NATURA 2000-Standard Data Form for Site GR2440004: Ethnikos Drymos Oitis. Database Release Date: 12/06/2020. Available online: https: / / natura2000.eea.europa.eu/Natura2000/SDF.aspx?site=GR2440004\#7 (accessed on 26 February 2021).

35. Adams, R. Junipers of the World: The Genius Juniperus, 4th ed.; Trafford Publishing: Bloomington, IN, USA, 2014; p. 422. ISBN 978-1490-723259.

36. Lesjak, M.M.; Beara, I.N.; Orčić, D.Z.; Ristić, J.D.; Anačkov, G.T.; Božin, B.N.; Mimica-Dukić, N.M. Chemical characterisation and biological effects of Juniperus foetidissima Willd. 1806. LWT Food Sci. Technol. 2013, 53, 530-539. [CrossRef]

37. Parvin Salehi, S.; Mirza, M.; Calagari, M. Composition of the essential oils of Junipers (Juniperus foetidissima and J. oblonga) from Arasbaran protected area. J. Essent. Oil Bear. Plants 2016, 19, 1261-1266. [CrossRef] 
38. Sahin Yaglioglu, A.; Eser, F.; Yaglioglu, M.S.; Demirtas, I. The antiproliferative and antioxidant activities of the essential oils of Juniperus species from Turkey. Flavour Fragr. J. 2020, 35, 511-523. [CrossRef]

39. Tunalier, Z.; Kirimer, N.; Baser, K. The composition of essential oils from various parts of Juniperus foetidissima. Chem. Nat. Compd. 2002, 38, 43-47. [CrossRef]

40. Junicoast. LIFE+ Nature Project "Actions for the Conservation of Coastal Dunes with Juniperus spp. in Crete adn the South Aegean (Greece)" LIFE07NAT/GR/000296. Available online: http:/ / www.junicoast.gr/ (accessed on 13 March 2021).

41. JunEx. LIFE+ Nature Project "Restoration and Conservation of the Priority Habitat Type *9562 Grecian Juniper Woods in Prespa National Park, Greece" LIFE12 NAT/GR/539. Available online: http:/ /www.junex.gr/index.php/en/ (accessed on 13 March 2021).

42. ForOpenForests. LIFE+ Nature Project “Conservation of Priority Forests and Forest Openings in "Ethnikos Drymos Oitis" and "Oros Kallidromo" of Sterea Ellada" LIFE11 NAT/GR/1014. Available online: https://www.foropenforests.org/en (accessed on 13 March 2021).

43. Tenerife, J. Life+ Nature Project Restauración de los Bosques Endémicos de Juniperus spp. en Tenerife LIFE04/NAT/ES/000064. Available online: https:/ / www.tenerife.es/life/index.htm (accessed on 13 March 2021).

44. Junipercy. LIFE+ Nature Project "Improving the Conservation Status of the Priority Habitat Type 9560* (Endemic Forests with Juniperus spp.) in Cyprus" LIFE10 NAT/CY/000717. Available online: https:/ / ec.europa.eu/environment/life/project/Projects/ index.cfm?fuseaction=search.dspPage\&n_proj_id=4069 (accessed on 13 March 2021).

45. Al Haddabi, L.; Victor, R. The ecological status of juniper woodlands in Al Jabal Al Akhdar, northern mountains of Oman. Int. J. Environ. Stud. 2016, 73, 746-759. [CrossRef]

46. MacLaren, C.A. Climate change drives decline of Juniperus seravschanica in Oman. J. Arid Environ. 2016, 128, 91-100. [CrossRef]

47. Tsopelas, P.; Barnes, I.; Wingfield, M.; Xenopoulos, S. Seiridium cardinale on Juniperus species in Greece. For. Pathol. 2007, 37, 338-347. [CrossRef]

48. Eastwood, A.; Lazkov, G.; Newton, A. The Red List of Trees of Central Asia; Fauna and Flora International: Campridge, UK, 2009; p. 31.

49. Patzelt, A. Photographic Field Guide to the Plants of the Western Hajar Mountains, Sultanate of Oman, with a Complete Checklist of Vascular Plant Species; Sultan Qaboos University, Academic Publication and Outreach Departmment: Muscat, Oman, 2015 ; p. 339.

50. Otto, R.; Barone, R.; Delgado, J.-D.; Arévalo, J.-R.; Garzón-Machado, V.; Cabrera-Rodríguez, F.; Fernández-Palacios, J.-M. Diversity and distribution of the last remnants of endemic juniper woodlands on Tenerife, Canary Islands. Biodivers. Conserv. 2012, 21, 1811-1834. [CrossRef]

51. Sarangzai, A.M.; Ahmed, M.; Ahmed, A.; Tareen, L.; Jan, S.U. The ecology and dynamics of Juniperus excelsa forest in BalochistanPakistan. Pak. J. Bot. 2012, 44, 1617-1625.

52. Allen, C.D.; Macalady, A.K.; Chenchouni, H.; Bachelet, D.; McDowell, N.; Vennetier, M.; Kitzberger, T.; Rigling, A.; Breshears, D.D.; Hogg, E.T. A global overview of drought and heat-induced tree mortality reveals emerging climate change risks for forests. For. Ecol. Manag. 2010, 259, 660-684. [CrossRef]

53. Teshome, D.T.; Zharare, G.E.; Naidoo, S. The Threat of the Combined Effect of Biotic and Abiotic Stress Factors in Forestry Under a Changing Climate. Front. Plant Sci. 2020, 11, 1874. [CrossRef] [PubMed]

54. Menzel, A.; Sparks, T.H.; Estrella, N.; Koch, E.; Aasa, A.; Ahas, R.; Alm-Kübler, K.; Bissolli, P.; Braslavská, O.g.; Briede, A.; et al. European phenological response to climate change matches the warming pattern. Glob. Chang. Biol. 2006, 12, 1969-1976. [CrossRef]

55. de Vries, S.M.; Alan, M.; Bozzano, M.; Burianek, V.; Collin, E.; Cottrell, J.; Ivankovic, M.; Kelleher, C.; Koskela, J.; Rotach, P. Pan-European strategy for genetic conservation of forest trees and establishment of a core network of dynamic conservation units. Eur. For. Genet. Resour. Programme 2015, 7, 3.

56. Fisher, M.; Gardner, A.S. The status and ecology of a Juniperus excelsa subsp. polycarpos woodland in the northern mountains of Oman. Vegetatio 1995, 119, 33-51. [CrossRef]

57. Hanna, S. Field Guide to the Geology of Oman. 1. Western Hajar Mountains and Musandam; Historical Association: Muscat, Oman, 1995; p. 178.

58. Solomou, A.; Proutsos, N.; Karetsos, G.; Tsagari, C. Effects of climate change on vegetation in Mediterranean forests: A review. Int. J. Environ. Agric. Biotechnol. 2017, 2, 240-247. [CrossRef]

59. Gruwez, R.; De Frenne, P.; De Schrijver, A.; Vangansbeke, P.; Verheyen, K. Climate warming and atmospheric deposition affect seed viability of common juniper (Juniperus communis) via their impact on the nutrient status of the plant. Ecol. Res. 2017, 32, 135-144. [CrossRef]

60. MacLaren, C.A. The Juniper \& Olive Survey Report, Vegetation Assessment: Part 1. In The Juniper and Olive Woodlands Project; The National Field Research Centre for Environmental Conservation, Oman Earthwatch Programme: Muscat, Oman, $2015 ;$ p. 41.

61. Karetsos, G.; Solomou, A.D.; Trigas, P.; Tsagari, K. The vascular flora of Mt. Oiti National Park and the surrounding area in Greece. J. For. Sci. 2018, 64, 435-454. [CrossRef]

62. Brofas, G.B.L.; Galanos, F.; Albanis, K. Management Plan for the National Park of Parnassus; Forest Research Institute of Athens: Athens, Greece, 1996. (In Greek)

63. Fisher, M. Decline in the juniper woodlands of Raydah Reserve in southwestern Saudi Arabia: A response to climate changes? Glob. Ecol. Biogeogr. Lett. 1997, 379-386. [CrossRef] 
64. IBM Corp. IBM SPSS Statistics for Windows; Version 23.0; IBM Corp.: Armonk, NY, USA, 2015. Available online: https: //www.ibm.com/analytics/spss-statistics-software (accessed on 25 February 2021).

65. Kendall, M.G. Rank Correlation Methods; Charles Griffin and Co. Ltd.: London, UK, 1948; p. 160.

66. Mann, H.B. Nonparametric tests against trend. Econom. J. Econom. Soc. 1945, 245-259. [CrossRef]

67. Helsel, D.R.; Hirsch, R.M. Statistical Methods in Water Resources; Elsevier: Amsterdam, The Netherlands, 1992 ; Volume 49.

68. Sen, P.K. Estimates of the regression coefficient based on Kendall's tau. J. Am. Stat. Assoc. 1968, 63, 1379-1389. [CrossRef]

69. Tsiros, I.X.; Nastos, P.; Proutsos, N.D.; Tsaousidis, A. Variability of the aridity index and related drought parameters in Greece using climatological data over the last century (1900-1997). Atmos. Res. 2020, 240, 104914. [CrossRef]

70. Emaminasab, M.; Oladi, R.; Pourtahmasi, K.; Shirvany, A. The potential of Juniperus foetidissima Willd. tree and Juniperus oblonga MB shrub for dendroclimatology in Arasbaran forests. For. Wood Prod. 2020, 73, 353-363. [CrossRef]

71. Proutsos, N.; Tigkas, D. Growth Response of Endemic Black Pine Trees to Meteorological Variations and Drought Episodes in a Mediterranean Region. Atmosphere 2020, 11, 554. [CrossRef]

72. Thanos, C.; Kaltsis, A.; Koutsovoulou, K.; Skourti, E.; Sarris, D. Composition and Structure of Juniperus macrocarpa Subpopulations. Final Report. Junicoast LIFE+ Nature Project: “Actions for the Conservation of Coastal Dunes with Juniperus spp. in Crete and the South Aegean (LIFE07NAT_GR_000296)"-Action A3. 2010, p. 81. Available online: http://www.junicoast.gr/ documents/0000/0048/LIFE_07_NAT_GR_000296_Deliverable_A.3rev1.pdf (accessed on 22 March 2021). (In Greek with English Executive Summary)

73. Gardner, A.S.; Fisher, M. The distribution and status of the montane juniper woodlands of Oman. J. Biogeogr. 1996, 23, 791-803. [CrossRef]

74. Ahmed, M.; Buzdar, A.; Shafiq, M. Pattern of change in seed characteristics in Juniperus excelsa in Baluchistan [Pakistan]. Pak. J. Agric. Res. 1989. [CrossRef]

75. Chambers, J.C.; Vander Wall, S.B.; Schupp, E.W. Seed and seedling ecology of pinon and juniper species in the pygmy woodlands of western North America. Bot. Rev. 1999, 65, 1-38. [CrossRef]

76. Gruwez, R.; De Frenne, P.; De Schrijver, A.; Leroux, O.; Vangansbeke, P.; Verheyen, K. Negative effects of temperature and atmospheric depositions on the seed viability of common juniper (Juniperus communis). Ann. Bot. 2014, 113, 489-500. [CrossRef] [PubMed]

77. Verheyen, K.; Adriaenssens, S.; Gruwez, R.; Michalczyk, I.M.; Ward, L.K.; Rosseel, Y.; Van den Broeck, A.; Garcia, D. Juniperus communis: Victim of the combined action of climate warming and nitrogen deposition? Plant Biol. 2009, 11, 49-59. [CrossRef]

78. Verheyen, K.; Schreurs, K.; Vanholen, B.; Hermy, M. Intensive management fails to promote recruitment in the last large population of Juniperus communis (L.) in Flanders (Belgium). Biol. Conserv. 2005, 124, 113-121. [CrossRef]

79. García, D. Interaction between juniper Juniperus communis L. and its fruit pest insects: Pest abundance, fruit characteristics and seed viability. Acta Oecol. 1998, 19, 517-525. [CrossRef]

80. Houle, G.; Babeux, P. Variations in rooting ability of cuttings and in seed characteristics of five populations of Juniperus communis var. depressa from subarctic Quebec. Can. J. Bot. 1994, 72, 493-498. [CrossRef]

81. Juan, R.; Pastor, J.; Fernandez, I.; Diosdado, J.C. Seedling emergence in the endangered Juniperus oxycedrus subsp. macrocarpa (Sm.) Ball in southwest Spain. Acta Biol. Cracov. Bot 2006, 48, 49-58.

82. Ward, L.K. The conservation of juniper: Longevity and old age. J. Appl. Ecol. 1982, 917-928. [CrossRef]

83. Milios, E.; Pipinis, E.; Petrou, P.; Akritidou, S.; Smiris, P.; Aslanidou, M. Structure and regeneration patterns of the Juniperus excelsa Bieb. stands in the central part of the Nestos valley in the northeast of Greece, in the context of anthropogenic disturbances and nurse plant facilitation. Ecol. Res. 2007, 22, 713-723. [CrossRef]

84. Quézel, P. Végétation des hautes montagnes de la Grèce méridionale. Vegetatio 1964, 289-385. [CrossRef]

85. Eriksson, G.; Namkoong, G.; Roberds, J.H. Dynamic gene conservation for uncertain futures. For. Ecol. Manag. 1993, 62, 15-37. [CrossRef]

86. Perrino, E.V.; Musarella, C.M.; Magazzini, P. Management of grazing Italian river buffalo to preserve habitats defined by Directive 92/43/EEC in a protected wetland area on the Mediterranean coast: Palude Frattarolo, Apulia, Italy. Euro-Mediterr. J. Environ. Integr. 2021, 6, 1-18. [CrossRef]

87. Calaciura, B.; Spinelli, O. Management of Natura 2000 Habitats. 5210 Arborescent Matorral with Juniperus spp. Technical Report 2008 10/24; European Commission (DG ENV B2): Brussels, Belgium, 2008; p. 25. Available online: https:/ / ec.europa.eu/environment/ nature/natura2000/management/habitats/pdf/5210_Arborescent_matorral_Juniperus.pdf (accessed on 22 March 2021). 